\title{
Spondilitis Tuberkulosis
}

\author{
I Gede Epi Paramarta, * Putu Siadi Purniti, * Ida Bagus Subanada, * Putu Astawa ** \\ * Bagian Ilmu Kesehatan Anak Fakultas Kedokteran Universitas Udayana Rumah Sakit Sanglah Denpasar \\ ** Bagian Ilmu Bedah Ortopedi Fakultas Kedokteran Universitas Udayana Rumah Sakit Sanglah Denpasar
}

\begin{abstract}
Spondilitis tuberkulosis adalah infeksi pada tulang belakang yang disebabkan oleh kuman Mycobacterium tuberculosis. Sejak obat anti tuberkulosis dikembangkan dan peningkatan kesehatan masyarakat, tuberkulosis tulang belakang menjadi menurun di daerah negara industri, meskipun tetap menjadi penyebab yang bermakna di negara berkembang. Gejala yang ditimbulkan antara lain demam, keringat terutama malam hari, penurunan berat badan dan nafsu makan, terdapat masa di tulang belakang, kiposis, kadang-kadang berhubungan dengan kelemahan dari tungkai dan paraplegi. Spondilitis tuberkulosis dapat menjadi sangat destruktif. Berkembangnya tuberkulosis di tulang belakang berpotensi meningkatkan morbiditas, termasuk defisit neurologi yang permanen dan deformitas yang berat. Pengobatan medikamentosa atau kombinasi antara medis dan bedah dapat mengendalikan penyakit spondilitis tuberkulosis pada beberapa pasien. (Sari Pediatri 2008;10(3):177-83).
\end{abstract}

Kata kunci: spondilitis tuberkulosis, anak

S pondilitis tuberkulosis (TB) atau dikenal dengan Pott's disease adalah penyakit infeksi yang disebabkan oleh kuman Mycobacterium tuberculosis yang mengenai tulang belakang. Spondilitis TB telah ditemukan pada mumi dari Spanyol dan Peru pada tahun $1779 .{ }^{1}$ Infeksi Mycobakcterium tuberculosis pada tulang belakang terbanyak disebarkan melalui infeksi dari diskus. Mekanisme infeksi terutama oleh penyebaran melalui hematogen. ${ }^{1}$ Secara epidemiologi tuberkulosis merupakan penyakit infeksi pembunuh nomor satu di dunia, 95\% kasus berada di negara berkembang. Organisasi kesehatan dunia (WHO) pada tahun 2000 memperkirakan 2 juta penduduk terserang dan 3 juta penduduk di seluruh

\footnotetext{
Alamat Korespondensi:

Dr. I Gede E. Paramarta Bag/SMF Ilmu Kesehatan Anak FK UNUD RSUP Sanglah Denpasar. Jl. P Nias, tlp/Fax 0361-244038, Denpasar
}

dunia meninggal oleh karena TB..$^{2,3}$ Insiden spondilitis TB masih sulit ditetapkan, sekitar 10\% dari kasus TB ekstrapulmonar merupakan spondilitis TB dan 1,8\% dari total kasus TB. ${ }^{2}$ Komplikasi spondilitis TB dapat mengakibatkan morbiditas yang cukup tinggi yang dapat timbul secara cepat ataupun lambat. Paralisis dapat timbul secara cepat disebabkan oleh abses, sedangkan secara lambat oleh karena perkembangan dari kiposis, kolap vertebra dengan retropulsi dari tulang dan debris. ${ }^{3}$

\section{Epidemiologi}

Berdasarkan laporan WHO, kasus baru TB di dunia lebih dari 8 juta per tahun. Diperkirakan 20-33\% dari penduduk dunia terinfeksi oleh Mycobacterium tuberculosis. Indonesia adalah penyumbang terbesar ketiga setelah India dan China yaitu dengan penemuan 
kasus baru 583.000 orang pertahun, kasus TB menular 262.000 orang dan angka kematian 140.000 orang pertahun. ${ }^{1,3}$ Kejadian TB ekstrapulmonal sekitar 4000 kasus setiap tahun di Amerika, tempat yang paling sering terkena adalah tulang belakang yaitu terjadi hampir setengah dari kejadian TB ekstrapulmonal yang mengenai tulang dan sendi. ${ }^{1,4}$ Tuberkulosis ekstrapulmonal dapat terjadi pada 25\%-30\% anak yang terinfeksi TB. TB tulang dan sendi terjadi pada 5\%-10\% anak yang terinfeksi, dan paling banyak terjadi dalam 1 tahun, namun dapat juga 2-3 tahun kemudian.

\section{Etiologi}

Tuberkulosis merupakan penyakit infeksi yang disebabkan oleh kuman Mycobacterium tuberculosis yang merupakan anggota ordo Actinomicetales dan famili Mycobacteriase. Basil tuberkel berbentuk batang lengkung, gram positif lemah yaitu sulit untuk diwarnai tetapi sekali berhasil diwarnai sulit untuk dihapus walaupun dengan zat asam, sehingga disebut sebagai kuman batang tahan asam. Hal ini disebabkan oleh karena kuman bakterium memiliki dinding sel yang tebal yang terdiri dari lapisan lilin dan lemak (asam lemak mikolat). Selain itu bersifat pleimorfik, tidak bergerak dan tidak membentuk spora serta memiliki panjang sekitar 2-4 $\mu \mathrm{m} .^{5}$

\section{Patogenesis}

Paru merupakan port d'entree lebih dari 98\% kasus infeksi TB, karena ukuran bakteri sangat kecil 1-5 $\mu$, kuman TB yang terhirup mencapai alveolus dan segera diatasi oleh mekanisme imunologis nonspesifik. Makrofag alveolus akan memfagosit kuman TB dan sanggup menghancurkan sebagian besar kuman TB. Pada sebagian kecil kasus, makrofag tidak mampu menghancurkan kuman TB dan kuman akan bereplikasi dalam makrofag. Kuman TB dalam makrofag yang terus berkembang-biak, akhirnya akan menyebabkan makrofag mengalami lisis, dan kuman TB membentuk koloni di tempat tersebut. Lokasi pertama koloni kuman TB di jaringan paru disebut fokus primer Ghon. ${ }^{5}$

Diawali dari fokus primer kuman TB menyebar melalui saluran limfe menuju ke kelenjar limfe regional, yaitu kelenjar limfe yang mempunyai saluran limfe ke lokasi fokus primer. Penyebaran ini menyebabkan terjadinya inflamasi di saluran limfe (limfangitis) dan di kelenjar limfe (limfadenitis) yang terkena. Jika fokus primer terletak di lobus bawah atau tengah, kelenjar limfe yang akan terlibat adalah kelenjar limfe parahilus, sedangkan jika fokus primer terletak di apeks paru, yang akan terlibat adalah kelenjar paratrakeal. Kompleks primer merupakan gabungan antara fokus primer, kelenjar limfe regional yang membesar (limfadenitis) dan saluran limfe yang meradang (limfangitis).

Masa inkubasi TB biasanya berlangsung dalam waktu 4-8 minggu dengan rentang waktu antara 2-12 minggu. Dalam masa inkubasi tersebut, kuman tumbuh hingga mencapai jumlah $10^{4}$ yaitu jumlah yang cukup untuk merangsang respons imunitas selular. ${ }^{6,7}$ Pada saat terbentuk kompleks primer, infeksi TB primer dinyatakan telah terjadi. Hal tersebut ditandai oleh terbentuk hipersensitivitas terhadap protein tuberkulosis, yaitu timbulnya respons positif terhadap uji tuberkulin. Selama masa inkubasi, uji tuberkulin masih negatif. Setelah kompleks primer terbentuk, imunitas selular tubuh terhadap TB telah terbentuk. Pada sebagian besar individu dengan sistem imun yang berfungsi baik, begitu sistem imun selular berkembang, proliferasi kuman TB terhenti. Namun, sejumlah kecil kuman TB dapat tetap hidup dalam granuloma. Bila imunitas selular telah terbentuk, kuman TB baru yang masuk ke dalam alveoli akan segera dimusnahkan.,

Setelah imunitas selular terbentuk fokus primer di jaringan paru biasanya mengalami resolusi secara sempurna membentuk fibrosis atau kalsifikasi setelah mengalami nekrosis perkijuan dan enkapsulasi. Kelenjar limfe regional juga akan mengalami fibrosis dan enkapsulasi tetapi penyembuhannya biasanya tidak sesempurna fokus primer di jaringan paru. Kuman TB dapat tetap hidup dan menetap selama bertahun-tahun dalam kelenjar tersebut. ${ }^{7}$

Di dalam koloni yang sempat terbentuk dan kemudian dibatasi pertumbuhannya oleh imunitas selular, kuman tetap hidup dalam bentuk dorman. Fokus tersebut umumnya tidak langsung berlanjut menjadi penyakit, tetapi berpotensi untuk menjadi fokus reaktivasi, disebut sebagai fokus Simon. Bertahun-tahun kemudian, bila daya tahan tubuh pejamu menurun, fokus Simon ini dapat mengalami reaktivasi dan menjadi penyakit TB di organ terkait, misalnya meningitis, TB tulang dan lain-lain., ${ }^{2,3,7}$

Selama masa inkubasi, sebelum terbentuknya imunitas selular, dapat terjadi penyebaran limfogen 
dan hematogen. Pada penyebaran limfogen, kuman menyebar ke kelenjar limfe regional membentuk kompleks primer sedangkan pada penyebaran hematogen kuman TB masuk ke dalam sirkulasi darah dan menyebar ke seluruh tubuh. Adanya penyebaran hematogen inilah yang menyebabkan TB disebut sebagai penyakit sistemik. ${ }^{6}$

Penyebaran hematogen yang paling sering terjadi adalah dalam bentuk penyebaran hematogenik tersamar (occult hematogenic spread), kuman TB menyebar secara sporadik dan sedikit demi sedikit sehingga tidak menimbulkan gejala klinis. Kuman TB kemudian akan mencapai berbagai organ di seluruh tubuh. Organ yang dituju adalah organ yang mempunyai vaskularisasi baik, misalnya otak, tulang, ginjal, dan paru sendiri, terutama apeks paru atau lobus atas paru. Bagian pada tulang belakang yang sering terserang adalah ${ }^{8}$ peridiskal terjadi pada 33\% kasus spondilitis TB dan dimulai dari bagian metafisis tulang, dengan penyebaran melalui ligamentum longitudinal. Anterior terjadi sekitar 2,1\% kasus spondilitis TB. Penyakit dimulai dan menyebar dari ligamentum anterior longitudinal. Radiologi menunjukkan adanya skaloping vertebra anterior, sentral terjadi sekitar $11,6 \%$ kasus spondilitis TB. Penyakit terbatas pada bagian tengah dari badan vertebra tunggal, sehingga dapat menyebabkan kolap vertebra yang menghasilkan deformitas kiposis. Di berbagai lokasi tersebut, kuman TB akan bereplikasi dan membentuk koloni kuman sebelum terbentuk imunitas selular yang akan membatasi pertumbuhan. ${ }^{6,7}$

\section{Manifestasi Klinik}

Seperti manifestasi klinik pasien TB pada umumnya, pasien mengalami keadaan sebagai berikut, berat badan menurun selama 3 bulan berturut-turut tanpa sebab yang jelas, demam lama tanpa sebab yang jelas, pembesaran kelenjar limfe superfisial yang tidak sakit, batuk lebih dari 30 hari, terjadi diare berulang yang tidak sembuh dengan pengobatan diare disertai benjolan/masa di abdomen dan tanda-tanda cairan di abdomen. . $^{1-4,7,8}$

Manifestasi klinis pada spondilitis TB tidak ditemukan pada bayi di bawah 1 tahun. Penyakit ini baru muncul setelah anak belajar berjalan atau melompat. Gejala pertama biasanya dikeluhkan adanya benjolan pada tulang belakang yang disertai oleh nyeri. Untuk mengurangi rasa nyeri, pasien akan enggan menggerakkan punggungnya, sehingga seakan-akan kaku. Pasien akan menolak jika diperintahkan untuk membungkuk atau mengangkat barang dari lantai. Nyeri tersebut akan berkurang jika pasien beristirahat. Keluhan deformitas pada tulang belakang (kyphosis) terjadi pada 80\% kasus disertai oleh timbulnya gibbus yaitu punggung yang membungkuk dan membentuk sudut, merupakan lesi yang tidak stabil serta dapat berkembang secara progresif. Terdapat 2 tipe klinis kiposis yaitu mobile dan rigid. Pada $80 \%$ kasus, terjadi kiposis $10^{\circ}, 20 \%$ kasus memiliki kiposis lebih dari $10^{\circ}$ dan hanya $4 \%$ kasus lebih dari $30^{\circ}$. Kelainan yang sudah berlangsung lama dapat disertai oleh paraplegia ataupun tanpa paraplegia. Abses dapat terjadi pada tulang belakang yang dapat menjalar ke rongga dada bagian bawah atau ke bawah ligamen inguinal. ${ }^{1,9,10}$

Paraplegia pada pasien spondilitis TB dengan penyakit aktif atau yang dikenal dengan istilah Pott's paraplegi, terdapat 2 tipe defisit neurologi ditemukan pada stadium awal dari penyakit yaitu dikenal dengan onset awal, dan paraplegia pada pasien yang telah sembuh yang biasanya berkembang beberapa tahun setelah penyakit primer sembuh yaitu dikenal dengan onset lambat. ${ }^{11}$

\section{Pemeriksaan penunjang}

Pemeriksaan rutin yang biasa dilakukan untuk menentukan adanya infeksi Mycobacterium tuberculosis adalah dengan menggunakan uji tuberkulin (Mantoux tes). Uji tuberkulin merupakan tes yang dapat mendeteksi adanya infeksi tanpa adanya menifestasi penyakit, dapat menjadi negatif oleh karena anergi yang berat atau kekurangan energi protein. Uji tuberkulin ini tidak dapat untuk menentukan adanya TB aktif. Pemeriksaan laju endap darah (LED) dilakukan dan LED yang meningkat dengan hasil $>100 \mathrm{~mm} / \mathrm{jam}$. Pemeriksaan radiologi pada tulang belakang sangat mutlak dilaksanakan untuk melihat kolumna vertebralis yang terinfeksi pada 25\%-60\% kasus. Vertebra lumbal I paling sering terinfeksi. Pemeriksaan radiologi dapat ditemukan fokus infeksi pada bagian anterior korpus vertebre dan menyebar ke lapisan subkondral tulang.

Pada beberapa kasus infeksi terjadi di bagian anterior dari badan vertebrae sampai ke diskus intervertebrae yang ditandai oleh destruksi dari end plate. Elemen posterior biasanya juga terkena. Penyebaran ke 
diskus intervertebrae terjadi secara langsung sehingga menampakkan erosi pada badan vertebra anterior yang disebabkan oleh abses jaringan lunak. Ketersediaan computerized tomography scan (CT scan) yang tersebar luas dan magnetic resonance scan (MR scan) telah meningkat penggunaannya pada manajemen TB tulang belakang. CT scan dikerjakan untuk dapat menjelaskan sklerosis tulang belakang dan destruksi pada badan vertebrae sehingga dapat menentukan kerusakan dan perluasan ekstensi posterior jaringan yang mengalami radang, material tulang, dan untuk mendiagnosis keterlibatan spinal posterior serta keterlibatan sacroiliac join dan sacrum. Hal tersebut dapat membantu memandu biopsi dan intervensi perencanaan pembedahan. Pemeriksaan $C T$ scan diindikasikan bila pemeriksaan radiologi hasilnya meragukan. Gambaran $C T$ scan pada spondilitis TB tampak kalsifikasi pada psoas disertai dengan adanya kalsifikasi periperal. ${ }^{9}$ Magnetic resonance imaging (MRI) dilaksanakan untuk mendeteksi massa jaringan, appendicular TB, luas penyakit, dan penyebaran subligamentous dari debris tuberculous.

Biopsi tulang juga dapat bermanfaat pada kasus yang sulit, namun memerlukan tingkat pengerjaan dan pengalaman yang tinggi serta pemeriksaan histologi yang baik. Pada pemeriksaan histologi akan ditemukan nekrosis kaseosa dan formasi sel raksasa, sedangkan bakteri tahan asam tidak ditemukan dan biakan sering memberikan hasil yang negatif. ${ }^{11}$

\section{Diagnosis}

Diagnosis spondilitis TB dapat ditegakkan dengan jalan pemeriksaan klinis secara lengkap termasuk riwayat kontak dekat dengan pasien $\mathrm{TB}$, epidemiologi, gejala klinis dan pemeriksaan neurologi. Metode pencitraan modern seperti $X$ ray, CT scan, MRI dan ultrasound akan sangat membantu menegakkan diagnosis spondilitis TB, pemeriksaan laboratorium dengan ditemukan basil Mycobacterium tuberculosis akan memberikan diagnosis pasti. ${ }^{10,11}$

\section{Diagnosis banding}

Spondilitis TB dapat dibedakan dengan infeksi piogenik yang menunjukkan gejala nyeri di daerah infeksi yang lebih berat. Selain itu juga terdapat gejala bengkak, kemerahan dan pasien akan tampak lebih toksis dengan perjalanan yang lebih singkat dan mengenai lebih dari 1 tingkat vertebrae. Tetapi gambaran yang spesifik tidak ada sehingga spondilitis TB sulit dibedakan dengan infeksi piogenik secara klinis. ${ }^{12}$ Selain itu spondilitis TB juga dapat dibedakan dengan tumor, yang menunjukkan gejala tidak spesifik.

\section{Tata laksana}

Saat ini pengobatan spondilitis TB berdasarkan terapi diutamakan dengan pemberian obat anti TB dikombinasikan dengan imobilisasi menggunakan korset. ${ }^{11,12}$ Pengobatan non-operatif dengan menggunakan kombinasi paling tidak 4 jenis obat anti tuberkulosis. Pengobatan dapat disesuaikan dengan informasi kepekaan kuman terhadap obat. Pengobatan INH dan rifampisin harus diberikan selama seluruh pengobatan. ${ }^{6,12}$

Regimen 4 macam obat biasanya termasuk INH, rifampisin, dan pirazinamid dan etambutol. Lama pengobatan masih kontroversial. Meskipun beberapa penelitian mengatakan memerlukan pengobatan hanya 6-9 bulan, pengobatan rutin yang dilakukan adalah selama 9 bulan sampai 1 tahun. Lama pengobatan biasanya berdasarkan dari perbaikan gejala klinis atau stabilitas klinik pasien. ${ }^{13}$ Obat yang biasa dipakai untuk pengobatannya seperti pada Tabel 1 .

Tabel 1. Obat tuberkulosis, dosis, dan efek samping ${ }^{6}$

\begin{tabular}{|c|c|c|}
\hline Nama obat & $\begin{array}{l}\text { Dosis harian } \\
(\mathrm{mg} / \mathrm{kgBB} / \mathrm{hr})\end{array}$ & Efek samping \\
\hline Izoniazid & $\begin{array}{l}5-15(300 \\
\mathrm{mg})\end{array}$ & $\begin{array}{l}\text { Hepatitis, neuritis perifer, } \\
\text { hipersensitivitas }\end{array}$ \\
\hline Rifampisin & $\begin{array}{l}10-20(600 \\
\mathrm{mg})\end{array}$ & $\begin{array}{l}\text { Gastrointestinal, } \\
\text { reaksi kulit, hepatitis, } \\
\text { trombositopenia, ensim } \\
\text { hepar, cairan tubuh } \\
\text { berwarna oranye }\end{array}$ \\
\hline Pyrazinamid & $15-40(2)$ & $\begin{array}{l}\text { Toksisitas hepar, artralgia, } \\
\text { gastrointestinal }\end{array}$ \\
\hline Ethambutol & $15-25(2,5)$ & $\begin{array}{l}\text { Neuritis optik, } \\
\text { penurunan visus, } \\
\text { hipersensitif, } \\
\text { gastrointestinal }\end{array}$ \\
\hline Streptomisin & $15-40(1)$ & Ototoksik, nefrotoksik \\
\hline
\end{tabular}

Sumber: Rahajoe NN, Basir D, Makmuri MS. Pedoman Nasional TB anak. 
Pemberian obat bila dikombinasikan antara INH dan rifampisin maka dosis dari INH tidak boleh lebih dari 10 $\mathrm{mg} / \mathrm{KgBB} / \mathrm{hr}$ dan dosis rifampisin tidak boleh lebih dari $15 \mathrm{mg} / \mathrm{kgBB} / \mathrm{hr}$ serta dalam meracik tidak boleh diracik dalam satu puyer tetapi pada saat minum obat dapat bersamaan. Sebagai tambahan terapi, anti inflamasi non steroid kemungkinan digunakan lebih awal pada penyakit dengan inflamasi superfisial membran yang non spesifik untuk menghambat atau efek minimalisasi destruksi tulang dari prostaglandin..$^{10-11,14}$

Selain memberikan medikamentosa, imobilisasi regio spinalis harus dilakukan. Sedikitnya ada 3 pemikiran tentang pengobatan Potts paraplegi. Menurut Boswots Compos (dikutip dari 10) pengobatan yang paling penting adalah imobilisasi dan artrodesis posterior awal. Dikatakan bahwa $80 \%$ pasien yang terdeteksi lebih awal akan terdeteksi lebih awal; akan pulih setelah arthrodesis. Menurut pendapatnya, dekompresi anterior diindikasikan hanya pada beberapa pasien yang tidak pulih setelah menjalani artrodesis. Bila pengobatan ini tidak memberikan perbaikan dan pemulihan, akan terjadi dekompresi batang otak. Pada umumnya artrodesis dilakukan pada spinal hanya setelah terjadi pemulihan lengkap..$^{15,16,17}$

Pengobatan non operatif dari paraplegia stadium awal akan menunjukkan hasil yang meningkat pada setengah jumlah pasien dan pada stadium akhir terjadi pada seperempat jumlah pasien pasien. Jika terjadi Pott's paraplegia maka pembedahan harus dilakukan. Indikasi pembedahan antara lain, ${ }^{18,19,20,21}$

A. Indikasi absolut

Paraplegi dengan onset yang terjadi selama pengobatan konservatif, paraplegia memburuk atau menetap setelah dilakukan pengobatan konservatif, kehilangan kekuatan motorik yang bersifat komplit selama 1 bulan setelah dilakukan pengobatan konservatif, paraplegia yang disertai spastisitas yang tidak terkontrol oleh karena suatu keganasan dan imobilisasi tidak mungkin dilakukan atau adanya risiko terjadi nekrosis akibat tekanan pada kulit, paraplegia yang berat dengan onset yang cepat, dapat menunjukkan tekanan berat oleh karena kecelakaan mekanis atau abses dapat juga merupakan hasil dari trombosis vaskular tetapi hal ini tidak dapat didiagnosis, paraplegia berat lainnya, paraplegia flaksid, paraplegia dalam keadaan fleksi, kehilangan sensoris yang komplit atau gangguan kekuatan motoris selama lebih dari 6 bulan.
B. Indikasi relatif

Paraplegia berulang yang sering disertai paralisis sehingga serangan awal sering tidak disadari, paraplegia pada usia tua, paraplegia yang disertai nyeri yang diakibatkan oleh adanya spasme atau kompresi akar saraf serta adanya komplikasi seperti batu atau terjadi infeksi saluran kencing.

Prosedur pembedahan yang dilakukan untuk spondilitis TB yang mengalami paraplegi adalah costrotransversectomi, dekompresi anterolateral dan laminektomi. Prosedur tata laksana pasien dengan komplikasi neurologi dapat dilihat seperti Gambar 1.

\section{Komplikasi}

Komplikasi yang dapat terjadi adalah kiposis berat. Hal ini terjadi oleh karena kerusakan tulang yang terjadi sangat hebat sehingga tulang yang mengalami destruksi sangat besar. Hal ini juga akan mempermudah terjadinya paraplegia pada ekstremitas inferior yang dikenal dengan istilah Pott's paraplegia. ${ }^{20,21}$

\section{Prognosis}

Prognosis spondilitis TB bervariasi tergantung dari manifestasi klinik yang terjadi. Prognosis yang buruk berhubungan dengan TB milier, dan meningitis TB, dapat terjadi sekuele antara lain tuli, buta, paraplegi, retardasi mental, gangguan bergerak dan lain-lain. Prognosis bertambah baik bila pengobatan lebih cepat dilakukan. Mortalitas yang tinggi terjadi pada anak dengan usia kurang dari 5 tahun sampai 30\%., ${ }^{6,16,17}$

\section{Kesimpulan}

Spondilitis TB adalah merupakan masalah penyakit yang kompleks dengan manifestasi klinis yang bervariasi. Pemeriksaan radiografi mutlak diperlukan untuk menegakkan diagnosis serta follow up penyakit. Jika dalam pemeriksaan didapatkan normal, salah satu pemeriksaan jaringan harus dikerjakan untuk menyingkirkan spondilitis TB. Tata laksana ditentukan oleh ada tidaknya paralisis atau paraplegi pada ekstremitas inferior sehingga pembedahan harus segera dilakukan. Prognosis tergantung dari perjalanan penyakit, tata laksana dan komplikasi yang menyertai. 


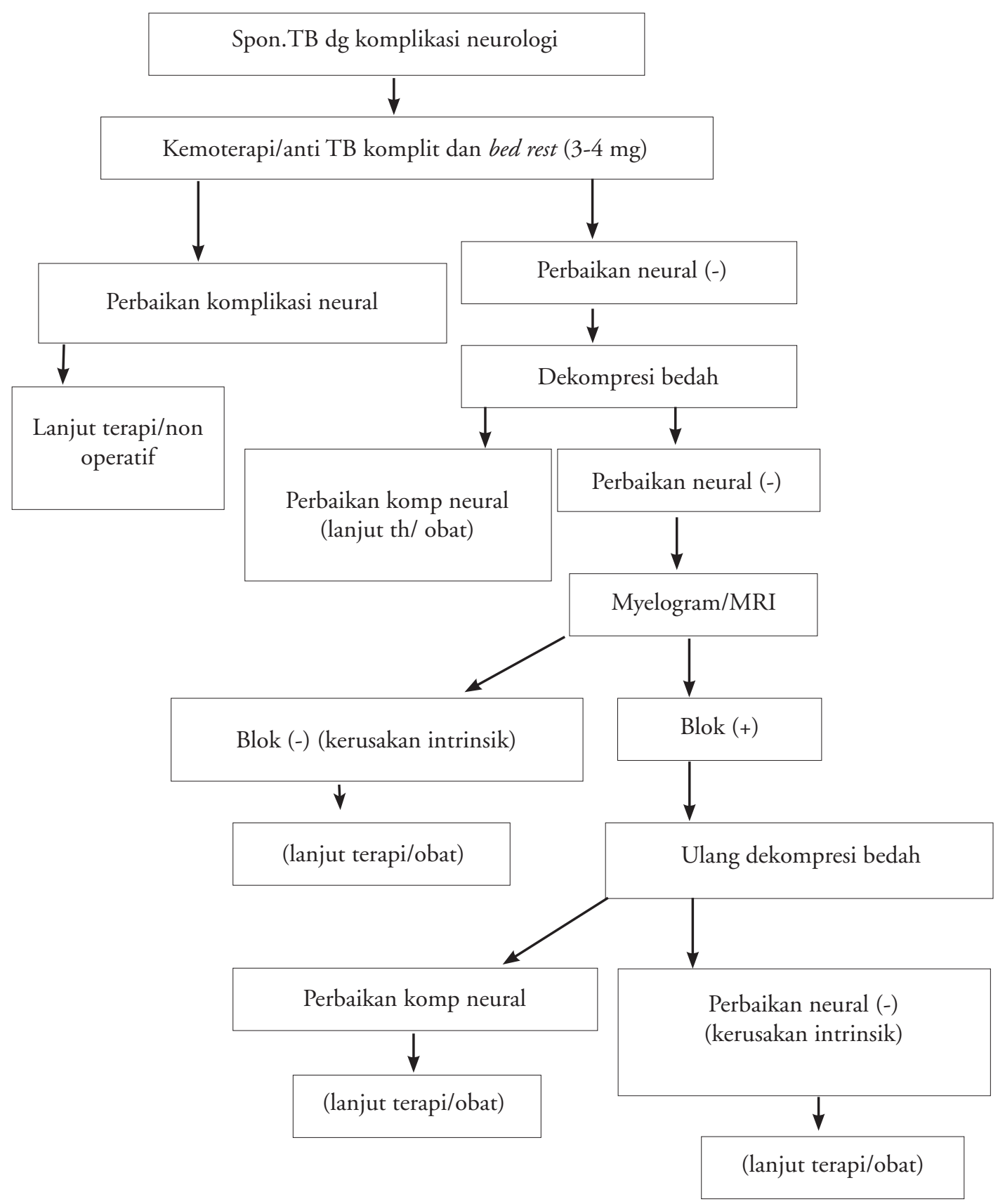

Gambar 1. Algoritme tata laksana spondilitis TB dengan komplikasi neurologi

\section{Daftar Pustaka}

1. Hidalgo A. Pott disease (tuberculous spondylitis). Didapat dari http:// www.emedicine.com/med/topic1902.htm. Diakses tanggal 9 Maret 2005.

2. Herchline T. Tuberculosis. Didapat dari http:// www. emedicine.com/med/topic2324.htm. Diakses tanggal 9 Maret 2005.
3. Batra V. Tuberculosis. Didapat dari http:// www.emedicine. com/ped/topic2321.htm. Diakses tanggal 9 Maret 2005.

4. Salim Samuel S, Hsu L. Tuberculous spondylitis. Didapat dari: URL: http://www.gentili.net/frame. asp? ID = 823\% $U R L I D=313541$. Diakses tanggal 9 Maret 2005

5. Utji R, Harun H. Kuman tahan asam. Dalam: Syarurahman A, Chatim A, Soebandrio AWK. penyunting. Buku ajar mikrobiologi Kedokteran. Edisi revisi. Jakarta: 
Binarupa Aksara; 1994. h. 191-9.

6. Rahajoe NN, Basir D, Makmuri MS. Pedoman nasional TB anak. Edisi ke 1. Jakarta: UKK Pulmunologi PP IDAI; 2005. h. 17-28.

7. Munoz FM, Starke JR. Tuberculosis. Dalam: Berhman, RE, Kliegman RM, Jenson HB, penyunting. Nelson Textbook of Pediatric. Edisi ke-17. Philadelphia: WB Saunders Company; 2004. h. 958-72.

8. Harisinghani MG, McLoud TC, Shepard JO, Ko JP. Tuberculosis from head to toe1. Radiographics: 2000; 20:449-70.

9. Anonim. Tuberculosis. Didapat dari http://www.wheelessonline.com/ortho/tuberculosis. Diakses tanggal 9 Maret 2005.

10. Anonim. Tuberculous arthritis. Didapat dari http://www. pennhealth.com/ency/article/000417.htm. Diakses tanggal 9 Maret 2005.

11. Anonim. Tuberculous spondylitis, Didapat dari http:// www.wheelessonline.com/ortho/tuberculous spondylitis. Diakses tanggal 9 Maret 2005.

12. Vali .P, Chaloupka R. Management of tuberculous spondylitis. Scripta Medica (Brno) 2000;3:165-8

13. Müller I. Mistakes in the diagnosis and treatment of tuberculous spondylitis. A case study. Scripta Medica (Brno) 2000; 3:157 -60.

14. Rahajoe NN. Berbagai masalah diagnosis dan tatalaksana tuberculosis anak. Dalam: Rahajoe N, Rahajoe NN, Boediman I, Said M, Wirjodiardjo M, Supriatno B.
Penyunting. Perkembangan dan masalah pulmunologi anak saat ini. Pendidikan Kedokteran Berkelanjutan Ilmu Kesehatan Anak FKUI XXXIII. FKUI; Jakarta: BP FKUI, 1994.

15. Crofton J, Horne N, Fred M. Tuberkulosis pada anak. Dalam: Tuberkulosis klinis. Harun N, penyunting. Edisi ke 2. Jakarta: Widya Medika; 2002. h. 31-79.

16. Anil K, Jail MS. Treatment of tuberculosis of the spine with neurologic complication. Clinical orthopaedics and related research 2002; 398:75-84.

17. Mankin H. The back. Dalam: Solomon L, Warwick D, Nayagam S. Penyunting. System of orthopaedics and fractures. Edisi ke 8. New York: Oxford University Press; 2001.h.371-404.

18. Wood GW. Infection of spine. Dalam: Crenshaw AH, penyunting. Champbell's operative orthopaedics. Edisi ke 7. New York: Mosby Company; 1987. h. 332342.

19. Resnick D. Osteomyelitis, septic arthritis, and soft tissue infection: organism. Dalam: Chaterin F, penyunting. Bone and joint imaging. Edisi ke 2. Philadelphia: WB Saunders; 1996. h. 684-716.

20. Banerjee A, Tow DE. Tuberculous spondylitis Didapat dari http://www.med. harvard.edu /JPNM/BoneTF /Case14/ WriteUp14.html. Diakses tanggal 27 April 2005).

21. Moon MS. Tuberculosis of the spine. Controversies and a new challenge. Spine: 1997; 15: 1791-7. 